The University of Akron

\title{
IdeaExchange@UAkron
}

Proceedings from the Document Academy

University of Akron Press Managed

January 2016

\section{Becoming Citizens: Dialogical Document Work in the Classroom of the People's Home}

Anna Hampson Lundh

University of Borås and Curtin University, anna.lundh@hb.se

Mats Dolatkhah

University of Borås, mats.dolatkhah@hb.se

Please take a moment to share how this work helps you through this survey. Your feedback will be important as we plan further development of our repository.

Follow this and additional works at: https://ideaexchange.uakron.edu/docam

Part of the Library and Information Science Commons

\section{Recommended Citation}

Lundh, Anna Hampson and Dolatkhah, Mats (2015) "Becoming Citizens: Dialogical Document Work in the Classroom of the People’s Home," Proceedings from the Document Academy: Vol. 2 : Iss. 1 , Article 14.

DOI: https://doi.org/10.35492/docam/2/1/14

Available at: https://ideaexchange.uakron.edu/docam/vol2/iss1/14

This Conference Proceeding is brought to you for free and open access by University of Akron Press Managed at IdeaExchange@UAkron, the institutional repository of The University of Akron in Akron, Ohio, USA. It has been accepted for inclusion in Proceedings from the Document Academy by an authorized administrator of

IdeaExchange@UAkron.For more information, please contact mjon@uakron.edu, uapress@uakron.edu. 


\section{INTRODUCTION}

The human activity of reading is studied in several different disciplines, ranging from literary studies to neuroscience. However, even though reading is considered important within and for institutions such as libraries, schools, and universities, reading research does not have a prominent position within Library and Information Science (LIS) (Wiegand, 2015). Within the discipline, there is a division between, on the one hand, reading research, often with interests in reading for pleasure (e.g. Howard, 2011; Toane \& Rothbauer, 2014), and, on the other hand, information behaviour/information practices research, where utilitarian information activities are often in focus (e.g. Case, 2012). There are also a few examples within the discipline where reading for pleasure has been conceptualised as a type of individual information behaviour (Ross, 1999a; 1999b; see also Frohmann, 2004a, pp. 81ff for a critique). In a recent paper (Lundh \& Dolatkhah, forthcoming), we have presented an argument for how reading - both reading for pleasure and utilitarian approaches to reading - can be studied within LIS as situated document work and simultaneously, as part of documentary practices.

The aim of this paper is twofold. Firstly, to analyse how a particular reading activity in a post-war Swedish comprehensive school, was part of the larger social and political project of the welfare state, and tied to the notion of good citizenship. Thereby, and secondly, we aim to illustrate how dialogical document theory enables the study of reading, and possibly other types of document work and practices. Through this theoretical perspective, reading is seen as taking place in localised activities, but at the same time related to levels of policy and societal change. In the following, these aims are fulfilled through a presentation of dialogical document theory and its subsequent operationalisation through an analysis of a historical situation where reading is practiced.

\section{DIALOGICAL DOCUMENT THEORY}

The framework for the study of reading as document work and as part of documentary practices proposed by Lundh and Dolatkhah (forthcoming) stems from the realisation that it is not necessarily fruitful to conceptualise reading as a type of information behaviour, information activity or information practice. Despite theoretical developments within LIS where individual-centred theories of information behaviour have been critiqued and alternative social theories of information practices have been suggested (e.g. Savolainen, 2007; "The behaviour/practice debate", 2009), it is difficult to break free from some of the underlying theoretical premises tied to the concept of information when reading is regarded as a type of information activity. 
Reading, in terms of information behaviour/practices, can be described as information use (see Lundh \& Limberg, 2012). However, the consequence of such a conceptualisation is that reading is reduced to a kind of behaviour or a social practice which entails the individual's decoding of information. Such a view of reading calls to mind - albeit unintentionally -models of information transfer and information processing (see Case, 2012, pp. 52ff; Linell, 2009, pp. 36ff; Olsson, 2010 , p. 68). Therefore, in relation to the study of reading, the concept of information is just as problematic as the concept of behaviour, as it easily leads to a disregard of the material, historically situated, and discursive aspects of reading.

A way forward from the idea of reading as the decoding of information is to understand reading as a situated meaning-making activity which involves the interpretation of semiotic signs or "inscriptions" (Linell, 2009, p. 21; Säljö, 2005, p. 96ff) on/in some type of document. The concepts of document work (McKenzie and Davies, 2010; McKenzie, Davies and Williams, 2014; Trace, 2007) and documentary practices (Frohmann, 2004a; 2004b) which stem from document theory developed within LIS during the past decades can be useful tools for conceptualising and studying reading. Reading, as performed and promoted in, for example, schools and libraries, is then to be understood as one important category of documentary practices and document work.

The concepts of document work and documentary practices are, in our view, complementary. By framing the concepts in dialogism, a kind of meta-theory described by Linell (2009) in his book Rethinking language, mind, and world dialogically, document work and documentary practices can be seen as two interrelated aspects of the work documents do in human practices and the work people accomplish through documents. While we use document work to denote activities with documents that happens and unfolds in specific situations, we consider documentary practices to be "situation-transcending" (Linell, 2009, p. 52). A dialogistic perspective highlights the constant interplay between activity and tradition and the importance of taking both levels into account when analysing human communication and interaction. In the following, an example of such an analysis is given.

\section{INTRODUCING THE STORY "AN EXCITING CHASE OF THIEVES"}

The empirical case in focus is an excerpt from a recorded Swedish lesson led by a male teacher on the afternoon of 27th March, 1968. The lesson is one of 223 Swedish lessons in year 6 (where most pupils are 12 years old) recorded in a large research project conducted by a group of researchers from Gothenburg University during the academic years of 1967/1968 and 1968/1969 (see Bredänge et al., 1971). All of these lessons have been digitised and reanalysed with a specific interest in reading activities and reading practices. 
Reading activities in school are seen here as examples of situations where document work occurs, and primary school is regarded as one - but not the only significant institutional setting for the forming of reading practices (see Pawley, 2009). Western traditions of reading carry certain notions of the kind of work that people should be doing with documents in different contexts. In schools, for example, this work is often centred on the comprehension of written text according to an a priori establishment of its meaning potentials. Reading promotion in libraries is often built on the notion that certain documents representing literary works should be used by patrons to generate meaningful, entertaining or potentially life-changing experiences. However, the intention of the present analysis is to describe reading as a societal practice, and not to evaluate the reading activities taking place in this particular situation, for example in terms of the individual cognitive skills of the students, or literary quality, or the efficacy of the teaching methods used.

The particular lesson discussed here is in many regards similar to most of the lessons in the data set: It goes on for 40 minutes, the teacher is mainly in front of the class, and the pupils sit at their desks working with a textbook. However, this specific lesson stands out, as it includes the teacher's long oral introduction to a story that the pupils are about to read in silence. The story is called "An Exciting Chase of Thieves" (in Swedish "En spännande tjuvjakt") and is found in a textbook anthology (Hammenhög, 1959). The introductory speech is an important part of the document work performed during the lesson as it is used to establish a frame for the pupils' work.

At first glance, the long introductory speech may seem like a mere digression from the planned content of the lesson. However, our interpretation is that the speech is used to connect the explicit levels of the story to wider issues of citizenship and social life. Thereby, it could be argued that the speech is an example of the notion of reading as an activity in which the reader is supposed to go 'beyond the text to its deeper meaning' expressed this idea by encouraging the use of fiction reading as a way of entering into discussions of ethics and social responsibilities (Läroplan för grundskolan, 1962, p. 146). Far from being a mere digression, then, the speech connects to a reading tradition by suggesting, or even imposing, a "deeper meaning" to the document which is about to be read.

The analysis of the speech focuses on the interplay between situated activity and sociocultural tradition in an instance of document work. It builds on a transcription in Swedish, and only the quotes used for illustrating the analysis has been translated to English. The transcription was made with a level of detail that

1 Today, this is a notion that has been promoted by for example writers in the print vs. digital reading debate (Wolf, 2008, p. 225; cf. Carr, 2010). The intention here is to highlight the historical idea - not to take a stance in the current debate. 
enables an analysis of the "sociocultural ecology" of this interaction (Linell, 2009, pp. 203f) which means its relationships to other communicative projects, activities, and practices. First, the interactional structure and organisation of the speech is described. This is followed by an examination of how wider historical and societal discourses are involved in the speech. Last, the empirical example will be discussed in terms of situated document work and its constant dialogue with socio-historical practices.

\section{OVERALL ORGANISATION OF THE SPEECH}

The recorded sequence with the teacher's introduction is just over eight minutes long and starts about 9 minutes into the lesson. The first minutes of the lesson are devoted to fluoride mouth rinsing, a preventive dental care activity introduced by the public dental services in the 1960's, where a dental professional would visit public school classrooms and let pupils rinse their mouths with a fluoride solution (see Gabre, Sköld and Olhede, 2008). When the dental professional leaves the classroom, the teacher initiates the document work to be performed through a discussion about the difference between fiction and nonfiction and the importance of understanding this difference. Thereafter, he announces that they are now going to read a fictional story, and the introductory speech begins.

The speech can be described as a "monologically organized" interaction (Linell, 2009, p. 166), with an "asymmetrical distribution of communicative labor" 2009, Linell, p. 193) where the teacher takes most of the speaking time. Throughout the sequence he asks questions that are targeted at specific students according to a pattern called an Initiation-Response-Evaluation (IRE) sequence (Mehan, 1979). This means that a question with a known response is asked by the teacher, a pupil produces a response, and the teacher evaluates this response. This pattern is evident in the very first part of the speech where the teacher addresses two different pupils with questions:

Teacher: We will read a story about a chase where there... there are some sportsmen involved. [pause] You can experience a lot during sports competitions. And [in] this story, we should note that too, they have benefited from their training, their sports training. We might... How can you benefit from... How can you benefit from participating in a sport?

Pupil 1: [the question is directed towards this pupil, who responds something inaudible which the teacher assents] 
Teacher: That is probably the greatest benefit. Are there any other benefits, something else that gives... when you are participating in competitions... Pupil 2?

Pupil 2: [responds something inaudible]

Teacher: Yes, my idea has always been that you should have something to do in your leisure time.

\section{Excerpt 1}

Even though the pupils' responses are inaudible in Excerpt 1, the structure and organisation of this interaction is clear as something that can be recognised as typical for teacher-led classroom interaction. As the speech goes on, the teacher puts questions of the same kind to four other pupils.

An interesting aspect of the whole sequence of the speech is that the actual activity of reading is explicitly mentioned only in the very beginning ("We will read a story..." in Excerpt 1) and at the very end (see Excerpt 2) when the teacher concludes and directs the pupils back towards the document containing the story:

Teacher: Yes, this is what we were supposed to be reading. Also thought that we would do some vocabulary exercises, but time is running and we have to look at the maths homework too, so we will have to turn to that page directly, page 22,"An Exciting Chase of Thieves".

\section{Excerpt 2}

The major part of the teacher's speech concerns what can be learnt from reading the story. In the speech, certain socio-historical resources - or discourses - can be identified. These discourses are discussed next.

\section{DISCOURSES OF GOOD CITIZENSHIP AND THE SWEDISH SPORTS MOVEMENT}

Throughout the speech, the teacher draws on a discourse of good citizenship and in particular how participation in the sports movement is edifying in this regard. As shown by Stark (2010), the sports movement played an important part in the $20^{\text {th }}$ century political project of building a democratic welfare state in Sweden, through its perceived role of fostering youth to certain desirable values. In the following, we understand discourse as "social representations: ways of looking at, 
thinking of and talking about particular topical domains" (Linell, 2009, p. 136). Through his utterances, situated in a specific location in time and space, the teacher is thus in dialogue with wider social and political discourses that transcend the particular classroom at the time of the lesson.

Hence, the teacher's speech can be understood against the backdrop of the societal and educational role of the sports movement in the Swedish post-war era. The moral of the story, which is formulated in the very beginning of the sequence and concerns the benefits of participating in sports, is a theme that continues as the speech unfolds, thereby explicating a potential and desirable level of meaning to be reached through the pupils' interpretive work with the document.

The first benefit of sports participation that is mentioned by Pupil 1 in Excerpt 1 above is inaudible, but the second one which the teacher follows up on is sports as a meaningful leisure time activity. In Excerpt 3 (which is the direct continuation of Excerpt 1) the teacher contrasts sport activities with a less desirable alternative, namely hanging out in groups:

Teacher: But it shouldn't be just anything, just to make the time pass. And you could do anything, stand around in gangs and just hang about. [pause, possibly a pupil says something] No, it should be something more than just passing time, and then, naturally, to be in a sports club. It has great benefits. Why is that?

\section{Excerpt 3}

The question of "Why is that?" introduces a new but inaudible IRE sequence with a third pupil. However, the teacher immediately goes on to a new IRE sequence with another pupil in which he identifies aspects of what makes participation in a sports club a meaningful leisure time activity:

Teacher: Yes, but you have to choose friends who influence you and make you develop. You become a positive citizen. It becomes... You become happy and a nice person and so forth. You enjoy your life and things like that. So you have to choose your friends. Well, there we have one great benefit of joining a club of some sort. But what kind of [inaudible] kind of friends would find their way there? Good or bad ones? Pupil 4?

Pupil 4: [inaudible] 
Teacher: It is often the better ones. Why can you... Are there bad friends in clubs too, or bad people, bad...? Yes, of course there is. But I would like to say that there is a natural selection here.

\section{Excerpt 4}

One aspect identified in Excerpt 4 is thus that joining a sport club provides opportunities to choose friends of a certain kind, a kind that is subsequently described as "good" and as "the better ones". This possibility of choosing friends has desirable consequences for the individual, both in terms of personal happiness, and in terms of the individual's societal contributions, as a "positive citizen". The relationship between sport activities and good citizenship is clearly articulated. This line of argument is further elaborated in the speech, where the role of sports clubs' rules and regulations, as well as of society's rules at large, are highlighted, as in Excerpt 5 which immediately follows Excerpt 4:

Teacher: Because in a sports club, if it's a good sports club, there are rules and regulations. You can't do whatever you like, it is something... many things are in fact harmful, that... you're free to do anything. But life is certainly not like that. There are major limitations. Yes, there are many, many more rules and regulations than you could ever imagine! If you think about school's rules and regulations, the point of them is to train you to become a citizen. No, they often drop out, sort of thinking that this is... doesn't suit them, are not used to rules and regulations and sort of subordinating themselves to others. They are put [inaudible] So many times there is sort of a positive selection that join sports clubs.

\section{Excerpt 5}

In Excerpt 5 sports clubs are compared to "life", and the good, positive member of a sports club is related to the good citizen: both the sportsman and the citizen are willing to follow club rules and regulations and those of life in general. In the sports club, however, those who are not willing to follow rules and regulations "often drop out".

The role of school is also highlighted in Excerpt 5 as an institution preparing students for becoming citizens, through its rules and regulations. The teacher then refers to something that has been discussed previously in the class, possibly during their own sports lessons, namely overstepping the take-off in long jumping. Through IRE sequences with two pupils, the teacher states that over- 
stepping disqualifies a long jump and the teacher again emphasises the role of rules in sports clubs, which, he argues is more important there than in any "other organised association activity". The teacher concludes, before directing the students to the story on page 22 , by describing how sport club members become adult by learning to take responsibility, for example by becoming coaches or looking after club jerseys:

Teacher: [...] take responsibility, because that is what is most important when you become an adult. No-one else will help you then, you must be able to handle your own [inaudible]. If you are used to taking responsibility, standing up for yourself, doing what is right, well then you will be all right.

\section{Excerpt 6}

In summary, the discourses on participation in the sports movement and on good citizenship are clearly linked in the speech: sportsmen are educated through the sports movement, through the school system, and learn from their peers, they learn to follow rules, and they learn to take responsibility. Consequently, the implication is, they become competent adults and good, responsible citizens.

The ways in which the Swedish sports movement and good citizenship are talked about in the teacher's introductory speech could be understood as related to an overarching discourse of the Swedish Welfare State or "the People's Home" (in Swedish, "folkhemmet"). "The people's home" is a political notion tied to the:

[...] modern, rational and classless society which the Swedish Social Democrats tried to implement during its long period in government 1932-1976, and which subsequently has become an important ingredient in the Swedish self-image, and a symbol for Sweden generally. (Stark, 2010, p. 39, authors' translation)

One element of the formation of "the People's Home" was the Swedish sports movement. Organised competitive sports, both in terms of elite sports and as a form of exercise for the wider public, is a relatively new phenomenon, and is said to have been introduced in Sweden through influences from Great Britain in the late 1800s (Stark, 2010, pp. 94f). In his historical examination of the introduction of the sport of ice hockey in Sweden and the processes during the 1900s through which this sport became what can be considered a national sport, Stark (2010) paints a picture of how this process was intimately connected with the development of Swedish society in general. From having been a pleasure activity 
for the upper classes, organised sports such as ice hockey became an important building block in the Swedish Welfare State, both as local meeting-point and as a national symbol.

Furthermore, as Stark (2010, pp. 232ff) discusses, after the Second World War and into the early 1970s, organised sports became a part the political ambition of organising meaningful leisure time activities for children and youth. Tied to the institution of youth sports were ideals of Swedishness, conscientiousness and modesty (2010, pp. 234ff). Hence, the local discourses identified in the teacher's speech regarding sports and citizenship can be said to be in dialogue with overarching societal discourses. In the next section, this will be discussed in terms of dialogue between document work and documentary practices.

\section{DOCUMENT WORK AND DOCUMENTARY PRACTICES}

How can this speech, which might seem to be a digression from a story in a book which a group of pupils is about to read, be understood as document work and as part of documentary practices? What is central in the analysis of the sequence is the interaction around a document, in this case a textbook with short stories, and the discursive work that takes place in the interaction. Furthermore, this work is both shaped by and contributes to the shaping of documentary practices: ways of interacting with and around texts that form conventions and traditions which extend both backwards and forwards in time. In this case, and through establishing a set of values connected to the story, the speech can be seen as an attempt to school the pupils in the documentary practice of 'moving beyond the text' to its 'deeper levels of meaning'.

This specific case is an example of teaching which is one of many communicative activities that historically has played - and is still playing - an important role for the formation of reading traditions. What is particularly interesting about this example is how the teacher expresses the objectives of reading the story, by emphasising what can be learnt from its moral. These objectives, the above analysis suggests, can be seen as related to the discourse of the People's Home which was formed during a substantial era in Swedish history, partly through the edifying role ascribed to the sports movement. We have suggested earlier that reading, as manifested in school during this era, was framed by the particular dynamics between democratic progressivism and disciplinary elements that were part of the comprehensive school as a political project in postwar Sweden (Dolatkhah \& Lundh, 2014, see also Qvarsebo, 2013). This is also a fruitful way of understanding the lesson under scrutiny here. The intentions of forming a democratic, egalitarian society required the disciplining of 'positive' citizens whom the teacher describes: citizens, who are ready to follow the rules, take responsibility and who thereby realise a societal project. 
There are of course limitations to what can be said about this one example of document work. For example, it is impossible to determine whether the teacher's speech was typical for this teacher, and whether it was carefully planned (see Linell, 2009, pp. 194-195). It is also impossible to comment on the pupils' subsequent interpretations of the story. We contend, however, that this case, which is unusual in the context of the whole data set, is interesting, not because it offers possibilities of didactic evaluation or the evaluation of reading skills, but because it highlights how document work such as reading activities are value-laden activities, and tied into ideologies and political projects.

\section{CONCLUSION}

Our aims in this article have been to analyse how the document work of reading during a lesson in a post-war Swedish comprehensive school, was part of the larger social and political project of the welfare state, and thereby to illustrate the usefulness of a dialogical perspective on work and practices with documents. This theoretical framework is intended to be useful for studies in both utilitarian and pleasure oriented empirical contexts, with the potential of contributing to bridging a classic divide in the ethos of LIS as a discipline. By studying this kind of socially, historically, and materially situated document work as it unfolds in situ and at the same time as "situation-transcending" (Linell, 2009, p. 52), it is possible to create a better understanding of the history of document work, as well as the practices and traditions underpinning contemporary situated document work.

While the specifics in this example of document work are particular to the context of the Swedish post-war welfare state, the connections between reading, citizenship and morals are, in a general sense, known from other contexts such as early $20^{\text {th }}$ century Australian education (Green and McCormack, 2011). These connections thus seem to be worthy of further exploration in order to better understand the document work and documentary practices that developed during the $20^{\text {th }}$ century. 


\section{REFERENCES}

The behaviour/practice debate: a discussion prompted by Tom Wilson's review of

Reijo Savolainen's Everyday information practices: a social phenomenological perspective. Lanham, MD: Scarecrow Press, 2008. (2009), Information Research, Vol. 14, No. 2, paper 403, available at http://InformationR.net/ir/142/paper403.html

Bredänge, G., Gustafsson, B., Hallin, G., Ingvarson, A., Odhagen T. and Stigebrandt, E. (1971), Didaktisk processanalys: presentation av syften, uppläggning, undersökningsgrupper och mätinstrument samt några beskrivande data [Didactic process analysis: presentation of purposes, design, groups, measurement instruments and some descriptive data], Lärarhögskolan: Gothenburg.

Carr, N. (2010), The shallows: what the Internet is doing to our brains, Norton, New York.

Case, D.O. (2012), Looking for information: a survey of research on information seeking, needs, and behaviour, 3rd expanded ed., Emerald, Bingley.

Dolatkhah, M. and Lundh, A.H. (2014), Reading, democracy and discipline: premises for reading activities in Swedish primary schools from 1967 to 1969, In Lauristin, M. and Vihalemm, P. (Eds.), Reading in changing society, Tartu University Press, Tartu, pp. 144-157.

Frohmann, B.P. (2004a), Deflating information: from science studies to documentation, University of Toronto Press, Toronto.

- (2004b), Documentation redux: prolegomenon to (another) philosophy of information, Library Trends, Vol. 52, No. 3, pp. 387-407.

Gabre, P., Sköld, U.M. and Olhede, A. (2008), Populationsstrategins återkomst: tre landstings sätt att främja barns och ungdomars orala hälsa [Strategies for oral health promotion and oral disease prevention in three counties in Sweden], Tandläkartidningen, Vol. 100, No. 2, pp. 62-69.

Green, B. and Cormack, P. (2011), Literacy, nation, schooling: reading (in) Australia, In Tröhler, D., Popkewitz, T. S. and Labaree, D.F. (Eds.), Schooling and the making of citizens in the long nineteenth century: comparative visions, Routledge, London, pp. 240-261.

Hammenhög, W. (1959), En spännande tjuvjakt [An exciting chase of thieves], In Albjörn, E. and Carlson, H (Eds.), Läs och berätta: läsebok för enhetsskolans högstadium [Read and recount: a reader for the senior level of the comprehensive school], Natur och kultur, Stockholm.

Howard, V. (2011), The importance of pleasure reading in the lives of young teens: self-identification, self-construction and self-awareness, Journal of Librarianship and Information Science, Vol. 43, No. 1, pp. 46-55. 
Linell, P. (2009), Rethinking language, mind, and world dialogically: interactional and contextual theories of human sense-making, Information Age Publ., Charlotte, NC.

Lundh, A. and Limberg, L. (2012), Designing by decorating: the use of pictures in primary school, Information Research, Vol. 17, No. 3. Available at: http://informationr.net/ir/17-3/paper533.html

Lundh, A.H. and Dolatkhah, M. (forthcoming), Reading as dialogical document work: possibilities for library and information science, Journal of Documentation, Vol. 72, No. 1.

Läroplan för grundskolan [Curriculum for the compulsory school] (1962), Kungl. Skolöverstyrelsen, Stockholm.

McKenzie, P.J. and Davies, E. (2010), Documentary tools in everyday life: the wedding planner, Journal of Documentation, Vol. 66, No. 6, pp. 788 - 806.

McKenzie, P.J., Davies, E. and Williams, S. (2014), Information creation and the ideological code of managerialism in the work of keeping track, Information Research, Vol. 19, No. 2, available at http://InformationR.net/ir/192/paper614.html

Mehan, H. (1979), Learning lessons: social organization in the classroom, Cambridge, Mass., Harvard U.P.

Olsson, M. (2010), Michel Foucault: discourse, power/knowledge, and the battle for truth, In Leckie, G.J., Given, L.M and Buschman, J. (Eds.), Critical theory for library and information science: exploring the social from across the disciplines, Libraries Unlimited, Santa Barbara, Calif, pp. 63-74.

Pawley, C. (2009), Beyond market models and resistance: organizations as a middle layer in the history of reading, The Library Quarterly, Vol. 79, No. 1, pp. 73-93.

Qvarsebo, J.U.D. (2013), Swedish progressive school politics and the disciplinary regime of the school, 1946-1962: a genealogical perspective, Paedagogica Historica, Vol. 49, No. 2, pp. 217-235.

Ross, C.S. (1999a), Finding without seeking: the information encounter in the context of reading for pleasure, Information Processing and Management, Vol. 35, No. 6, pp. 783-799.

- (1999b), Finding without seeking: what readers say about the role of pleasurereading as a source of information, In Wilson, T.D. and Allen, D.K. (Eds.), Exploring the contexts of information behaviour: proceedings of the Second International Conference on Research in Information Needs Seeking and Use in Different Contexts, 13/15 August, 1998, Sheffield, UK, Taylor Graham: London, pp. 343-355.

Savolainen, R. (2007), Information behavior and information practice: reviewing the "umbrella concepts" of information seeking studies, The Library Quarterly, Vol. 77, No. 2, pp 109-132. 
Stark, T. (2010), Folkhemmet på is: ishockey, modernisering och nationell identitet i Sverige 1920-1972 [The people's home on ice: ice hockey, modernization and national identity in Sweden 1920-1972), Idrottsforum, Malmö, Diss.

Säljö, R. (2005), Lärande och kulturella redskap: om lärprocesser och det kollektiva minnet [Learning and cultural tools: on learning processes and the collective memory], Norstedts akademiska förlag, Stockholm.

Toane, C. and Rothbauer, P.M. (2014), "Pure delight and professional development": the reading practices and library use of an active poetry community, Canadian Journal of Information and Library Science, Vol. 38, No. 2, pp. 97-126.

Trace, C.B. (2007), Information creation and the notion of membership, Journal of Documentation, Vol. 63, No. 1, pp. 142-164.

Wiegand, W.A. (2015), "Tunnel vision and blind spots" reconsidered: Part of Our Lives (2015) as a test case, The Library Quarterly, Vol. 85, No. 4, pp. 347-370.

Wolf, M. (2008), Proust and the squid: the story and science of the reading brain. Harper Perennial, New York. 